\title{
Review of "DreamMakers: Innovating for the Greater Good" by Michele Hunt, DreamMakers (dreammakers.org)
}

Sang Lee(D)

\author{
Book details \\ Hunt, Michele \\ DreamMakers: Innovating for the Greater Good. \\ Saltaire, UK: Greenleaf Publishing; 2017. \\ 200 pages, ISBN13-978-1-78353-568-2
}

Keywords: Innovation, Greater social good, Social entrepreneurs, Brighter future,
This is an inspiring book about DreamMakers, those individuals and organizations that have the audacity to rethink, redesign, and co-create a new world view of doing well by doing good. These dream makers aspire to reset the workings of the world to alleviate major ills and problems that societies face today. To understand and appreciate this book fully, we need to know about the author.

Michele Hunt is an extraordinarily successful lady with colorful professional background. Upon graduation from college (BA in Sociology from Eastern Michigan University and MA in Sociology from University of Detroit), she worked for 9 years at a male prison of the Michigan Department of Corrections as the state's first female Deputy Warden of Rehabilitation Programs. Then, she moved on to Herman Miller, a Fortune 500 global office furniture company known for its people growing corporate culture through shared visions and values. She worked there for 13 years and rose to the position of Senior Vice President for People and reported directly to the wellknown CEO Max De Pree (author of Leadership is an Art). Then, Ms. Hunt was appointed as Director of the Federal Quality Institute by President Bill Clinton. Since 1995, Ms. Hunt has been running her own consulting firm for leadership development, organizational culture transformation, and of course DreamMakers projects. She has been a frequent keynote speaker at conferences and a popular consultant for major global corporations in the USA and abroad.

\section{Central theme of the book}

This book is about hope and dreams for a brighter future. Everyone realizes the rapid rate of change in the global environment and its impact on people's lives. While the world is flatter than before with the advances in technologies and connectivity, it is not any safer or

(c) The Author(s). 2017 Open Access This article is distributed under the terms of the Creative Commons Attribution 4.0 International License (http://creativecommons.org/licenses/by/4.0/), which permits unrestricted use, distribution, and reproduction in any medium, provided you give appropriate credit to the original author(s) and the source, provide a link to the Creative Commons license, and indicate if changes were made. 
equitable. As a matter of fact, the major social ills and problems around the world are getting worse rather than better. All leaders of governments, business firms, NGOs, and individuals try to be future smart. That is to predict how the future will be like so that people can be better prepared for it. However, the future that so many people strive to predict is most likely not the kind of future we aspire. The kind of future we would like is where we can have intelligent solutions to difficult problems so that we can have purposeful life, nurturing relationships, caring communities, financial security, physical and environmental wellbeing, and opportunities to learn and grow. To create such a smart future, we need dream makers who can chart new courses for global transformation to a better world. Such an ideal smart future can be only possible when we embrace new innovation models that emphasize collaboration, design thinking, and value co-creation for an inclusive, peopleoriented world. Such an enlightened way of defining and pursuing success is not new. However, the recent advances in digital connectivity and globalization are providing new tools to create a smart future where governments, business firms, social organizations, and ordinary citizens can co-create shared visions and goals for the greater good. The primary goal of DreamMakers is to create such a future where "organizations can excel, people can thrive, and nature can flourish." This is the main purpose of DreamMakers.

\section{Examples of DreamMakers}

Ms. Hunt has a fine collection of businesses and other organizations as agents of world benefit. Some of these entities are well-known global firms, university-based institutes, social enterprises, and also student organizations. They are all unique and different in their visions/goals and scale. However, there is the central theme which is to make a positive difference in the world to make it a better place to live, work, and enjoy life. In this review, we will highlight only several of the examples discussed in the book.

\section{Fowler Center for business as an agent of world benefit}

The Fowler Center was established at the Weatherhead School of Management, Case Western Reserve University. The mission of this center is "To advance new knowledge for transforming the world's most complex problems into business opportunities for industry leading innovation and world-shaping benefit." The center developed AIM2Flourish, a global project "to identify, recognize, celebrate and shine a light on the bestof the-best business innovation stories that serve the greater good." This project is supposed to be the largest student-led global learning platform which showcases business innovations that solve humanity's greatest challenges.

\section{B Corporation}

Currently, there are about 2000 firms in 50 countries in the B Corp community. The unifying goal of these firms is "people using business as a force for good." Certified B Corporations represents a global community of companies "that meet the highest standards of verified overall social and environmental performance, public transparency, and legal accountability." Some of the best-known firms that have joined B Corp include Beneficial State Bank (USA), Australian Ethical Investment, Caravela Coffee (Columbia), CarShare Atlantic (Canada), Off-Grid Solutions/WakaWaka (Netherlands), HCA (US), One Earth Designs (Hong Kong), and Kickstarter Crowdfunding (USA). 


\section{WakaWaka}

WakaWaka, cofounded by Maurice Green and Camile van Gestel of the Netherlands, aims to help provide light to 1.2 billion people around the world without access to electricity. In response to this global social problem of energy poverty, the founders created a device that is very efficient, low-cost, hand-held, solar-powered LED light and charger. WakaWaka can provide $150 \mathrm{~h}$ of light on a single charge from the sun and can charge cell phones, cameras, and USB-powered devices. It has been reported that over one million people in 43 countries are using over 200,000 WakaWakas. WakaWaka has been a very successful innovation for the greater good by doing well.

\section{NewWind and the WindTree}

NewWind was created by Jerome Michaud-Lariviere in 2011 to develop a windpower device that has an organic form and pleasant look. The clean energy generating WindTree stands $26 \mathrm{ft}$ tall with 54 artificial leaves that are elegantly designed. One WindTree can generate enough windpowered electricity to light 15 street lights or a typical household for a year. The potential benefits of WindTree is far reaching for the greater good, not only for developed countries but more so for many people suffering from energy poverty in underdeveloped nations.

\section{EAT Initiative}

EAT Initiative was founded by Dr. Gunhild Stordalen $(\mathrm{MD} / \mathrm{PhD})$ to meet the global challenge of providing the growing world population with a healthy and nutritious diet within safe environmental limits. EAT Initiative has become a global platform of research institutions, government agencies, business firms, philanthropic foundations, and nonprofits. These organizations come together as they have a shared goal to address the challenges of food, health, and sustainability for effectively supporting more than nine billion people and the planet by middle of this century. EAT Initiative believes healthy diet is one of the major solutions to sustain a healthy planet. While EAT is not the solution to all the obstacles and problems facing the food-related issues, it represents a model for co-creating solutions.

\section{Rid-All}

Rid-All was established by three close childhood friends who are social entrepreneurs. They reclaimed 3 acres of abandoned land in Cleveland, $\mathrm{OH}$, and transformed it into a thriving urban farm and learning center that provides healthy food to companies, institutions, and community. Rid-All has constructed three green houses, four hoop houses, and a pond to grow fruits, vegetables, and fish. In addition to being a model enterprise for urban farming, Rid-All also has other social programs to make the world a better place, such as the gun buy-back program to make the urban area safe. The three young black men who established Rid-All truly epitomize the power of shared vision and goals in transforming dreams into reality for the greater good.

\section{DreamMakers for a smart future}

In this book, Ms. Hunt challenges us to imagine what is possible about creating our future and the world. People are smart and capable of achieving extraordinary things for organizations and themselves. However, we need to ask some crucial questions. What 
is really important in life? What values do we need to embrace and pursue in the future? Most societies in the world use money as the measure of success. In the process, we have neglected the truly important values such as families, relationships, communities, and our planet. We need collective wisdom to co-create shared new values for the greater good. This book reminds us what needs to be done, what is possible, and how we can do it together.

Funding

The funding source of this review is TEMP-KSQM.

Author's information

Sang M. Lee is a University Eminent Scholar and Distinguished University Professor Emeritus at the University of Nebraska-Lincoln. He is the Editor-in-Chief of Service Business: An International Journal and International Journal of Quality Innovation, both Springer publications. Professor Lee is the former President of the Decision Sciences Institute (DSI) and currently serving as President of the Pan-Pacific Business Association. He is the author or co-author of 70 books and over 300 journal articles.

Competing interests

The author declares that he has no competing interests.

\section{Publisher's Note}

Springer Nature remains neutral with regard to jurisdictional claims in published maps and institutional affiliations.

\section{Submit your manuscript to a SpringerOpen ${ }^{\circ}$} journal and benefit from:

- Convenient online submission

- Rigorous peer review

- Open access: articles freely available online

- High visibility within the field

- Retaining the copyright to your article

Submit your next manuscript at $\boldsymbol{s p r i n g e r o p e n . c o m ~}$ 